\title{
Basic Fibroblast Growth Factor Protects against Rotenone- Induced Dopaminergic Cell Death through Activation of Extracellular Signal-Regulated Kinases 1/2 and Phosphatidylinositol-3 Kinase Pathways
}

\author{
Shih-Ling Hsuan, ${ }^{1 \star}$ Heather M. Klintworth, ${ }^{1 \star}$ and Zhengui Xia ${ }^{1,2}$ \\ ${ }^{1}$ Toxicology Program, Department of Environmental and Occupational Health Sciences, and ${ }^{2}$ Graduate Program in Neurobiology and Behavior, University \\ of Washington, Seattle, Washington 98195-7234
}

\begin{abstract}
Administration of rotenone to rats reproduces many features of Parkinson's disease, including dopaminergic neuron degeneration, and provides a useful model to study the pathogenesis of Parkinson's disease. However, the cell death mechanisms induced by rotenone and potential neuroprotective mechanisms against rotenone are not well defined. Here we report that rotenone-induced apoptosis in human dopaminergic SH-SY5Y cells is attenuated by pretreatment with several growth factors, most notably basic fibroblast growth factor (bFGF). bFGF activated both extracellular signal-regulated kinase 1/2 (ERK1/2) and phosphatidylinositol-3 kinase (PI3-kinase) pathways in SH-SY5Y cells. Ectopic activation of ERK1/2 or PI3-kinase protected against rotenone, whereas inhibition of either pathway attenuated bFGF protection. Reducing the expression of the proapoptotic protein Bcl-2-associated death protein (BAD) by small interfering RNA rendered SH-SY5Y cells resistant to rotenone, implicating BAD in rotenone-induced cell death. Interestingly, bFGF induced a long-lasting phosphorylation of BAD at serine 112, suggesting BAD inactivation through the ERK1/2 signaling pathway. Moreover, primary cultured dopaminergic neurons from mesencephalon were more sensitive to rotenone-induced cell death than nondopaminergic neurons in the same culture. The loss of dopaminergic neurons was blocked by bFGF, an inhibition dependent on ERK1/2 and PI3-kinase signaling. These data suggest that rotenone-induced dopaminergic cell death requires BAD and identify bFGF and its activation of ERK1/2 and PI3-kinase signaling pathways as novel intervention strategies to block cell death in the rotenone model of Parkinson's disease.
\end{abstract}

Key words: rotenone; apoptosis; bFGF; ERK1/2; PI3-kinase; BAD; neuron

\section{Introduction}

Parkinson's disease is a progressive neurodegenerative disorder affecting $>1 \%$ of the United States population over age 65 years; more than 1 million people in the United States suffer from this disease (Olanow and Tatton, 1999). It is characterized by degeneration of dopaminergic neurons in the substantia nigra pars compacta $(\mathrm{SNpc})$ and the presence of intracytoplasmic inclusions known as Lewy bodies that contain $\alpha$-synuclein aggregates.

At the onset of symptoms, $\sim 80 \%$ of dopaminergic neuron terminals in the caudate-putamen, and $\sim 60 \%$ of dopaminergic neurons in the substantia nigra are already lost in Parkinson's disease brains (Dauer and Przedborski, 2003). Although current therapy for Parkinson's disease focuses on symptomatic relief,

\footnotetext{
Received Nov. 18, 2005; revised Feb. 19, 2006; accepted March 16, 2006.

This work was supported by National Institutes of Health Grant ES 012215 (Z.X.).

*S.-L.H. and H.M.K. contributed equally to this work.

Correspondence should be addressed to Dr. Zhengui Xia, Department of Environmental and Occupational Health Sciences, University of Washington, Health Science Building, Box 357234, Room F561C, Seattle, WA 98195-7234. E-mail:zxia@u.washington.edu.

S.-L. Hsuan's present address: Graduate Institute of Veterinary Pathology, College of Veterinary Medicine, National Chung Hsing University, Taichung, 40227 Taiwan, Republic of China.

DOI:10.1523/JNEUROSCI.4922-05.2006

Copyright $\odot 2006$ Society for Neuroscience $\quad$ 0270-6474/06/264481-11\$15.00/0
}

there is a great need to identify neuroprotective therapies that will slow disease progression. There is reduced expression of various neurotrophic factors, including brain-derived neurotrophic factor, basic fibroblast growth factor (bFGF), glial-derived neurotrophic factor (GDNF), and ciliary neurotrophic factor, in Parkinson's disease brains (Tooyama et al., 1993; Howells et al., 2000; Siegel and Chauhan, 2000), suggesting a role for decreased neurotrophic signaling in degeneration of dopaminergic neurons. The elucidation of downstream mechanisms for trophic factor neuroprotection may identify new drug targets for Parkinson's disease therapy.

Despite intensive effort over the past two decades, the exact etiology of Parkinson's disease remains elusive. The majority (at least $90 \%$ ) of the cases are nonfamilial and sporadic with undefined cause. Nevertheless, epidemiological studies have suggested that occupational exposure to environmental toxicants, including pesticides, may contribute to the development of Parkinson's disease (Ramsden et al., 2001; Mouradian, 2002). The discovery of a link between the neurotoxicant 1-methyl-4-phenyl-1,2,3,6tetrahydropyridine (MPTP) and the development of Parkinson's disease in humans provided the first clue that environmental factors may contribute to Parkinson's disease (Langston et al., 1983; Ballard et al., 1985). Interestingly, chronic treatment of rats 
with rotenone causes dopaminergic neuron degeneration in the $\mathrm{SNpc}$ and the formation of $\alpha$-synuclein-containing inclusions (Betarbet et al., 2000). Rotenone is a mitochondrial complex I inhibitor and a naturally derived compound widely used as a pesticide in organic gardening and fishery management. Because it is lipophilic, rotenone crosses the blood-brain barrier readily. Because rotenone induces apoptotic cell death in cultured dopaminergic cells (King et al., 2001; Wang et al., 2002; Newhouse et al., 2004), it provides another useful model to study Parkinson's disease. However, mechanisms for rotenone-induced dopaminergic cell death have not been completely defined. Moreover, it is not clear whether this cell death can be prevented by growth factors and what the underlying mechanisms are. In this study, we report that rotenone-induced dopaminergic cell death requires the proapoptotic protein $\mathrm{Bcl}-2$-associated death protein (BAD), a member of the BH-3-only Bcl-2 family proteins. Furthermore, rotenone-induced cell death was inhibited by bFGF through activation of the extracellular signal-regulated kinase $1 / 2$ (ERK1/2) and phosphatidylinositol-3 kinase (PI3-kinase) signaling pathways.

\section{Materials and Methods}

Materials. The following plasmids have been described: the constitutively active mitogen-activated protein kinase kinase 1 (caMKK1) $(\Delta \mathrm{N} 3-$ S218E/S222D) (Mansour et al., 1994) and the constitutively active p110 $\left(\mathrm{p} 110^{*}\right)$ (Hu et al., 1995). The plasmid encoding enhanced green fluorescent protein (eGFP) was purchased from Clontech (Palo Alto, CA). The anti-phospho-ERK1/2 antibody was from Promega (Madison, WI), and the anti-ERK2 antibody was from Upstate Biotechnology (Lake Placid, NY). The anti-phospho-Ser473 Akt, anti-BAD, and antiphospho-Ser112 BAD antibodies were from Cell Signaling Technology (Beverly, MA). The anti-GFP monoclonal antibody was purchased from Invitrogen (Carlsbad, CA). The anti-apoptosis-inducing factor (AIF) (H-300), anti-Bcl-2, and anti-Bcl-xL antibodies were from Santa Cruz Biotechnology (Santa Cruz, CA). The anti-X-linked inhibitor of apoptosis protein (XIAP), anti- $\beta$-actin, anti-tyrosine hydroxylase (TH), and anti-GABA antibodies were from Sigma (Saint Louis, MO). The antiactive caspase-3 polyclonal antibody was purchased from R \& D Systems (Minneapolis, MN).

The following reagents were purchased commercially, and all trophic factors were recombinant proteins of human origin: rotenone (Sigma), bFGF (Chemicon, Temecula, CA), GDNF, U0126 [1,4-diamino-2,3-dicyano-1,4-bis $(o$ aminophenylmercapto) butadiene], and LY294002 [2-(4-morpholinyl)-8-phenyl-1(4H)benzopyran-4-one] (Calbiochem, La Jolla, CA), epidermal growth factor (EGF) (Becton Dickinson Labware, Bedford, MA), small interfering RNA (siRNA) of BAD (Cell Signaling Technology), a nonspecific double-stranded RNA oligomer and Oligofectamine (Invitrogen), and Fugene 6 (Roche, Indianapolis, IN).

Cell culture. SH-SY5Y cells, a human dopaminergic neuroblastoma cell line, were cultured in DMEM/F-12 (Invitrogen) supplemented with $10 \%$ fetal bovine serum (FBS), $50 \mathrm{U} / \mathrm{ml}$ penicillin, $50 \mu \mathrm{g} / \mathrm{ml}$ streptomycin, and $20 \mathrm{~mm}$ HEPES. Medium was changed every $2-3 \mathrm{~d}$. Cells were plated onto poly-D-lysine-coated 35 $\mathrm{mm}$ plates or 24 -well plates $1 \mathrm{~d}$ before drug treatment or transfection.

Primary ventral mesencephalic cultures were prepared from embryonic day 14 (E14) Sprague Dawley rats (Harlan, Indianapolis, IN) (Le et al., 2001). The ventral mesencephalon was dissected in PBS, pH 7.2 (Invitrogen), and cells were mechanically dissociated in DMEM (Invitrogen).
Dissociated cells were plated as micro-island cultures in 24-well plates containing Aclar coverslips coated with poly-D-lysine and laminin (BD Bioscience, Bedford, MA) at a seeding density of $7.5 \times 10^{4}$ cells per well. Primary cells were maintained in DMEM supplemented with 10\% FBS, 100 $\mathrm{U} / \mathrm{ml}$ penicillin, $100 \mu \mathrm{g} / \mathrm{ml}$ streptomycin, $25 \mathrm{~mm}$ HEPES, and $30 \mathrm{~mm}$ glucose at $37^{\circ} \mathrm{C}$ in a humidified incubator containing $93 \%$ air and $7 \% \mathrm{CO}_{2}$. One-half of media was changed at 24 and $72 \mathrm{~h}$. After $5 \mathrm{~d}$ in vitro (DIV5) and DIV7, one-half culture media was replaced with DMEM/F-12 containing 1\% N2 supplement (Invitrogen) and $10 \mu \mathrm{g} / \mathrm{ml}$ bovine serum albumin (BSA).

Transient transfection of SH-SY5Y cells with plasmid DNA or siRNA. Fugene 6 was used for transfection of plasmids according to the instructions of the manufacturer with minor modifications. Briefly, regular growth medium was replaced with low serum medium containing $0.5 \%$ FBS before transfection. Plasmids were mixed with Fugene 6 at 1:10 ratio and incubated at room temperature for $25 \mathrm{~min}$. The Fugene 6/DNA mixture was then added to cells to allow for transfection. One day after transfection, cells were trypsinized and plated onto 24 -well plates (with $12 \mathrm{~mm}$ coverslip) at a density of $2 \times 10^{5}$ cells per well and incubated for another $24 \mathrm{~h}$ before drug treatment.

Oligofectamine was used for transfection of siRNA per the instructions of the manufacturer. Briefly, $1 \mathrm{~d}$ before transfection, SH-SY5Y cells were seeded onto $35 \mathrm{~mm}$ tissue culture plates at a density of $8.2 \times 10^{5}$ cells per plate in antibiotic-free growth medium. One hundred nanomolar of BAD siRNA (siBAD) or a control nonspecific RNA oligomer (siNS) were mixed with OptiMEM (Invitrogen) and Oligofectamine for $20 \mathrm{~min}$ at room temperature. The mixture was then added to cells that have been placed in $1 \mathrm{ml}$ of antibiotic-free DMEM/F-12 medium supplemented with $0.5 \% \mathrm{FBS}$ and $10 \mathrm{~mm}$ HEPES. The cells were incubated at $37^{\circ} \mathrm{C}, 5 \%$ $\mathrm{CO}_{2}$ for $4 \mathrm{~h}$. Appropriate volume of DMEM/F-12 containing 30\% FBS and $10 \mathrm{mM} \mathrm{HEPES}$ were added to each plate to make a final concentration of FBS to $10 \%$. Cells were returned to a $37^{\circ} \mathrm{C}, 5 \% \mathrm{CO}_{2}$ incubator. One day after transfection, cells from the $35 \mathrm{~mm}$ plates were pooled and split onto 24-well plates and incubated for another day before drug treatment. Thus, among different drug treatment groups, cells transfected with the same reagent (e.g., siBAD or siNS) had the same transfection efficiency because they were from the same pool of transfected cells.

All cells were cotransfected with an expression vector encoding eGFP (0.25 of $\mu \mathrm{g}$ DNA/35 mm plate for siRNA transfection or 0.5 of $\mu \mathrm{g}$ DNA/35 mm plate for plasmid DNA transfection) as a marker for transfected cells. Transfected cells were identified by immunostaining with a monoclonal antibody to GFP and Alexa Fluor 488-conjugated goat antimouse IgG secondary antibody (Invitrogen). The percentage of apopto-
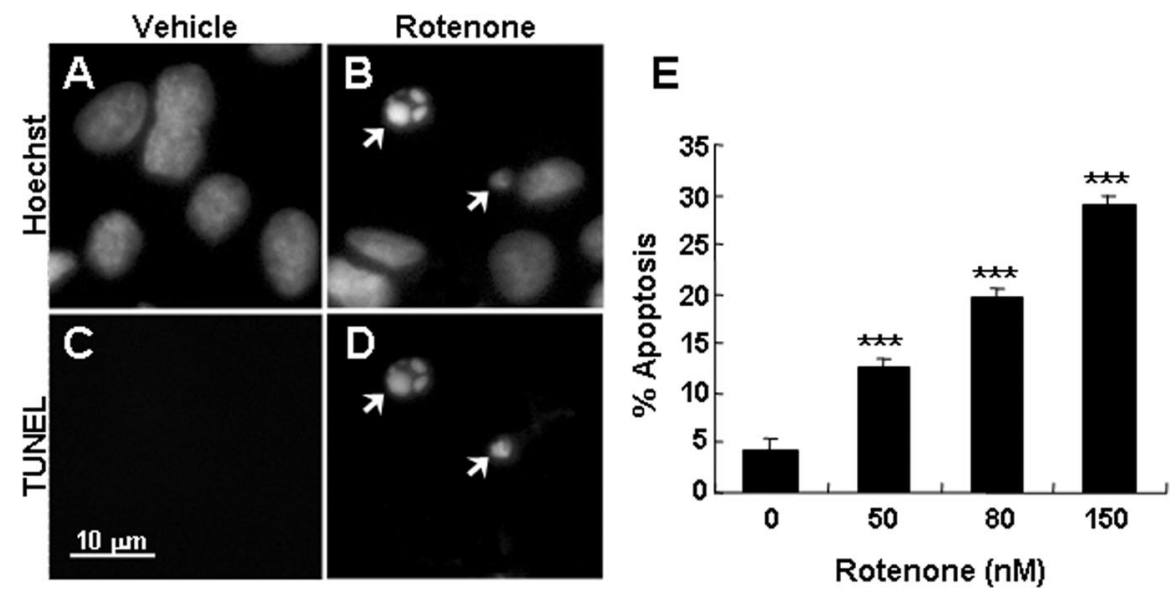

Figure 1. Rotenone induces apoptosis in SH-SY5Y cells. $\boldsymbol{A}-\boldsymbol{D}$, Representative photomicrographs of nuclear morphology $(\boldsymbol{A}, \boldsymbol{B})$ and TUNEL staining $(\boldsymbol{C}, \boldsymbol{D})$ of SH-SY5Y cells treated with vehicle control $(\boldsymbol{A}, \boldsymbol{C})$ or $50 \mathrm{~nm}$ rotenone for $24 \mathrm{~h}(\boldsymbol{B}, \boldsymbol{D})$. Nuclear morphology was visualized after Hoechst staining. Arrows identify cells with condensed or fragmented nuclei, characteristic of apoptosis. Scale bar, $10 \mu \mathrm{m}$. $\boldsymbol{E}$, Dose-response of rotenone-induced apoptosis. SH-SY5Y cells were treated with vehicle, 50, 80, or 150 nm rotenone for $24 \mathrm{~h}$. Apoptosis was scored based on nuclear morphology after Hoechst staining. Data are from four independent experiments of duplicate determinations. At least 8000 cells were counted for each data point. Error bars represent SEM. ${ }^{* * *} p<0.001$ (ANOVA) compared with control. 
tic cells in the total transfected cell population was quantified based on morphological changes (nuclear condensation/fragmentation).

Treatment with trophic factors and drugs. Rotenone, U0126, and LY294002 were dissolved in dimethylsulfoxide (DMSO), and DMSO was used as a vehicle control for these agents. When cell cultures were cotreated with rotenone and U0126 or LY294002, the final concentration of DMSO did not exceed $0.3 \%$. Trophic factors were dissolved in PBS containing $0.2 \%$ BSA, and PBS/BSA was used as a vehicle control for trophic factors. Because rotenone is highly lipophilic and may bind to proteins in the serum, SH-SY5Y cells were transferred into low serum medium containing $0.5 \%$ FBS before rotenone treatment to prevent excessive retention of rotenone in the serum. Trophic factors were added to the culture $1 \mathrm{~h}$ before rotenone. In experiments pretreated with bFGF and inhibitors, cells were transferred into low serum medium in the presence or absence of inhibitor for $1 \mathrm{~h}$, followed by another hour of bFGF treatment before addition of rotenone. Drug treatment of primary ventral mesencephalic cultures consisted of bFGF pretreatment for $1 \mathrm{~h}$, followed by rotenone with or without inhibitors for $24 \mathrm{~h}$. All treatments were administered on DIV7.

Apoptosis assay. Apoptosis was determined by nuclear condensation and/or fragmentation after Hoechst staining (Hetman et al., 1999). Healthy cells have evenly and uniformly stained nuclei. Based on cell body and nuclear morphological changes, we did not observe any nonapoptotic cell death under experimental conditions in this study. To obtain unbiased counting, slides were coded and cells were scored blindly without previous knowledge of treatment.

Terminal deoxynucleotidyl transferase-mediated biotinylated UTP nick end labeling. Terminal deoxynucleotidyl transferase (TDT)-mediated biotinylated UTP nick end labeling (TUNEL) staining was performed using TDT (Promega) according to the suggestions of the manufacturer. Briefly, cells were fixed with $4 \%$ paraformaldehyde (PFA) and permeabilized in PBS containing $0.1 \%$ Triton X-100 and $0.1 \%$ sodium citrate. Cells were then incubated with a TUNEL mixture containing $0.5 \mathrm{U} / \mu \mathrm{l}$ TDT, 0.2 nmol biotin-11-dUTP (PerkinElmer, Boston, MA), followed by streptavidin-FITC (Sigma). TUNEL staining was monitored under a fluorescence microscope.

Western analysis. Cell lysates were prepared as described previously (Dérijard et al., 1994), and $40 \mu \mathrm{g}$ of proteins was used for Western analysis. The intensity of the bands on immunoblots was quantified by analysis of the scanned blots using NIH ImageJ software (version 1.33u) and normalized to loading control.

Immunocytochemistry. After drug treatment, cells were fixed with $4 \%$ $\mathrm{PFA} / 4 \%$ sucrose at room temperature for $30 \mathrm{~min}$ and permeabilized with $0.5 \%$ Igepal (Sigma) in PBS for $30 \mathrm{~min}$. To block nonspecific binding, cells were treated for $2 \mathrm{~h}$ with $2.5 \%$ BSA, $5 \%$ horse serum, and $5 \%$ goat serum in $\mathrm{PBS} / 0.1 \%$ Triton X-100. Cells were then incubated with mouse anti-TH monoclonal antibody (1:500), anti-GABA (1:1000), or anti-AIF (1:50) antibody overnight at $4^{\circ} \mathrm{C}$. Secondary antibodies (goat anti-mouse Alexa Fluor 488, goat anti-rabbit Alexa Fluor 594, or goat anti-rabbit Alexa Fluor 488, respectively, at 1:500) were then added for $1 \mathrm{~h}$, followed by nuclear staining with Hoechst $33258(2.5 \mu \mathrm{g} / \mathrm{ml})$ for $10 \mathrm{~min}$. For double immunostaining, anti-AIF or anti-active caspase-3 $(0.2 \mu \mathrm{g} / \mathrm{ml})$ antibody was incubated overnight at $4^{\circ} \mathrm{C}$, followed by anti-TH antibody for $1 \mathrm{~h}$ at room temperature. Secondary antibodies (goat anti-rabbit Alexa Fluor 488 plus goat anti-mouse Alexa Fluor 594, or goat anti-rabbit Alexa Fluor 594 plus goat anti-mouse Alexa Fluor 660, respectively, at 1:500) were then added for $1 \mathrm{~h}$, followed by nuclear staining with Hoechst 33258 for 10 min.

Statistical analysis. Data were from at least two independent experiments, each with duplicate or triplicate determinations. Statistical analysis of data were performed using one-way ANOVA. Error bars represent SEM.

\section{Results}

Rotenone induces apoptosis in SH-SY5Y cells in a concentration-dependent manner

To study mechanisms of rotenone-induced cell death, human dopaminergic SH-SY5Y cells were treated with varying concentrations of rotenone for $24 \mathrm{~h}$, and cell death was monitored by staining cells with the DNA dye Hoechst 33258 to visualize nu-
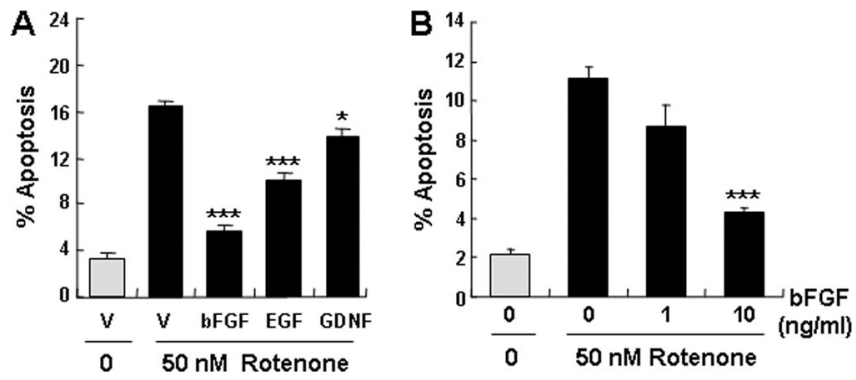

Figure 2. Effect of growth factors on rotenone-induced SH-SY5Y cell apoptosis. A, SH-SY5Y cells were preincubated with $10 \mathrm{ng} / \mathrm{ml} \mathrm{bFGF,} \mathrm{EGF,} \mathrm{or} \mathrm{GDNF} \mathrm{for} 1 \mathrm{~h}$ before treatment with $50 \mathrm{~nm}$ rotenone for $24 \mathrm{~h}$. B, Dose-response of bFGF protection. Cells were preincubated with $0-10$ $\mathrm{ng} / \mathrm{ml}$ bFGF for $1 \mathrm{~h}$, followed by $50 \mathrm{~nm}$ rotenone treatment for $24 \mathrm{~h}$. Data are from two independent experiments of triplicate determinations. At least 6000 cells were counted for each data point. Error bars are SEM. ${ }^{*} p<0.05,{ }^{* * *} p<0.001$ (ANOVA) compared with cells treated with rotenone only. V, Vehicle.

clear morphology or with TUNEL. Some of the nuclei of rotenone-treated cells appeared condensed and fragmented, hallmarks of morphological changes associated with apoptosis (Fig. $1 A, B)$. SH-SY5Y cells with fragmented or condensed nuclei were also positively labeled with TUNEL after rotenone treatment (Fig. 1C,D). Rotenone-induced apoptosis was dose dependent (Fig. 1E). In the remainder of the studies described below, we treated SH-SY5Y cells with $50 \mathrm{~nm}$ rotenone. This concentration was chosen because it approximates the estimated concentrations of rotenone found in rat brains in the in vivo studies (Betarbet et al., 2000) and is comparable with that used to study rotenone neurotoxicity by other investigators (30-100 nM) (Betarbet et al., 2000; Sherer et al., 2001; Lee et al., 2002; Wang et al., 2002; Newhouse et al., 2004).

\section{Growth factor protection of SH-SY5Y cells against rotenone-induced apoptosis}

It has been postulated that the downregulation of various trophic factors in substantia nigra contributes to the death of dopaminergic neurons in Parkinson's disease brains (Siegel and Chauhan, 2000). To evaluate the effect of trophic factors on rotenoneinduced apoptosis, SH-SY5Y cells were pretreated with $10 \mathrm{ng} / \mathrm{ml}$ bFGF, EGF, or GDNF for $1 \mathrm{~h}$, followed by $50 \mathrm{~nm}$ rotenone treatment for $24 \mathrm{~h}$. These growth factors significantly reduced rotenone-induced apoptosis (Fig. 2). Among them, bFGF offered the most potent protection; $10 \mathrm{ng} / \mathrm{ml}$ bFGF reduced apoptosis by $65 \%$. Thus, we focused on elucidating neuroprotective mechanisms afforded by bFGF.

\section{Both ERK1/2 and PI3-kinase pathways are crucial for bFGF protection against rotenone}

bFGF can activate several signal transduction pathways that have been implicated in neuroprotection against different forms of cellular insult (Hetman et al., 1999; Desire et al., 2000; Pardo et al., 2002; Chang et al., 2004). To investigate the underlying mechanisms responsible for bFGF protection against rotenone, $\mathrm{SH}$ SY5Y cells were stimulated with bFGF for $0-30 \mathrm{~min}$ and analyzed for activation of ERK1/2 and PI3-kinase pathways by Western blot analysis. bFGF induced phosphorylation of ERK1/2 and Akt (Fig. 3A), indicative of activation of ERK1/2 and PI3-kinase pathways.

To determine whether activation of ERK1/2 or PI3-kinase signaling contributes to bFGF protection against rotenone, we used LY294002, a PI3-kinase inhibitor (Vlahos et al., 1994; Yao and 


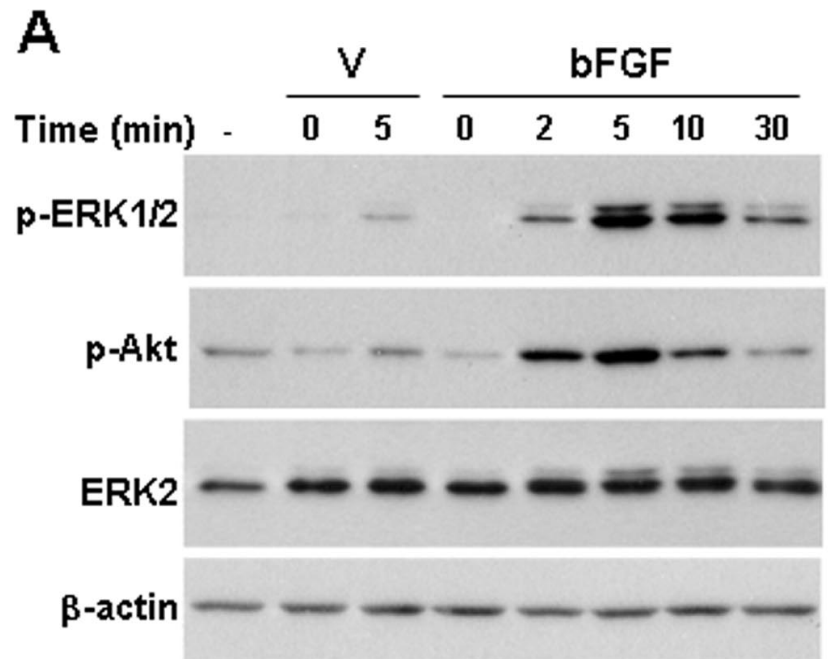

B
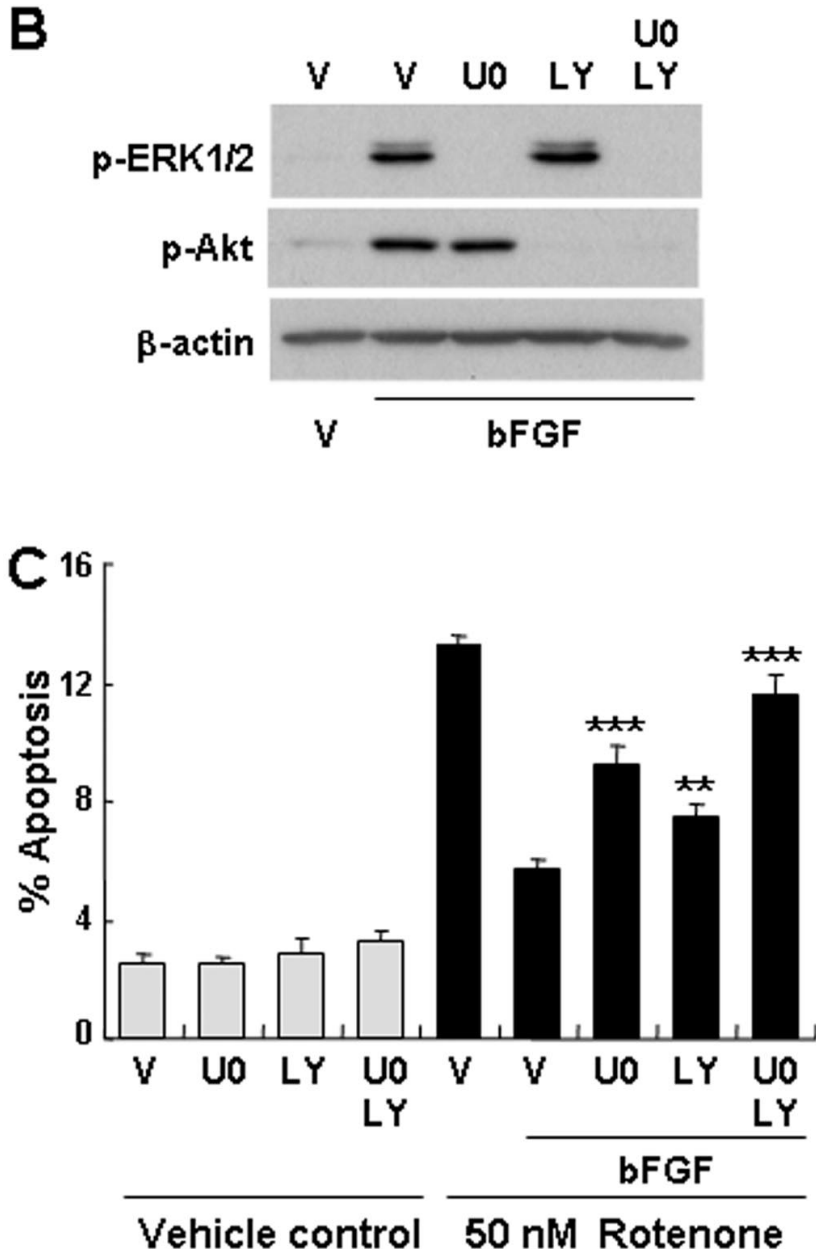

Figure 3. bFGFprotects SH-SY5Y cells against rotenone via activation ofERK1/2 and PI3-kinase. $\boldsymbol{A}$, Kinetics of ERK1/2 and PI3-kinase activation by $10 \mathrm{ng} / \mathrm{ml}$ bFGF. B, SH-SY5Y cells were pretreated with vehicle control DMSO (V), $10 \mu \mathrm{m}$ U0126 (U0), or $10 \mu \mathrm{m}$ LY294002 (LY) for $1 \mathrm{~h}$ before bFGF stimulation (10 ng/ml, $5 \mathrm{~min}$ ). Cell lysates were harvested and subjected to Western blot analysis for phosphoERK1/2 (p-ERK1/2) or phospho-Akt (p-Akt). $\beta$-Actin and total ERK2 were used as loading controls. Immunoblots were representative of three independent experiments. C, Inhibition of ERK1/2 or PI3kinase pathways reverses bFGF protection against rotenone. SH-SY5Y cells were pretreated with vehicle control, $10 \mu \mathrm{m}$ U0126, or $10 \mu \mathrm{m}$ LY294002 for $1 \mathrm{~h}$, followed by $10 \mathrm{ng} / \mathrm{ml}$ bFGF for another hour before incubation with rotenone $(50 \mathrm{~nm}, 24 \mathrm{~h})$. Data are from two independent experiments of triplicate determinations. At least 6000 cells were counted for each data point. Error bars are SEM. ${ }^{* *} p<$ $0.01,{ }^{* * *} p<0.001$ (ANOVA) compared with cells cotreated with rotenone and bFGF.

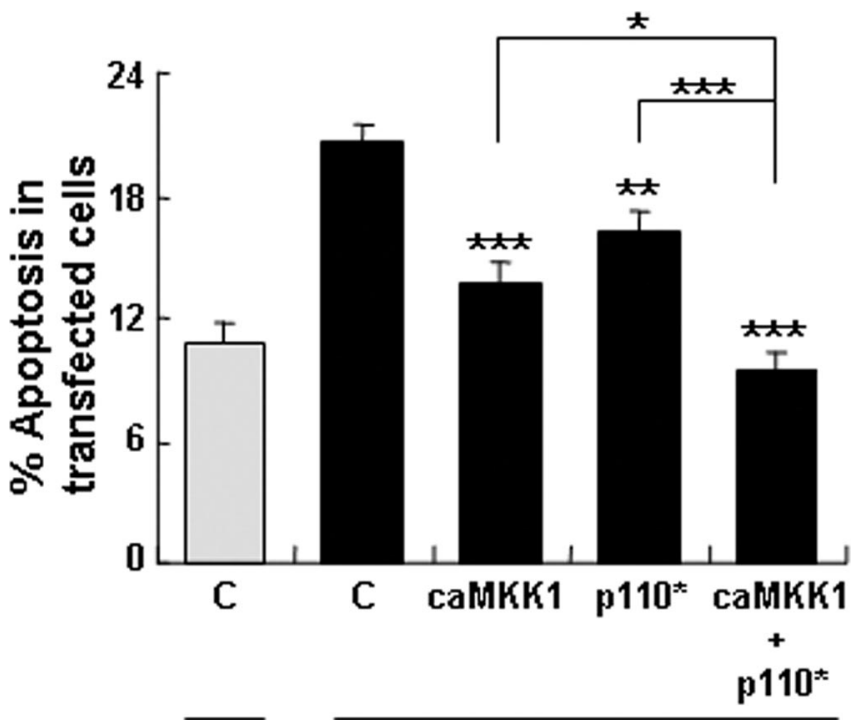

$50 \mathrm{nM}$ Rotenone

Figure 4. Activation of ERK1/2 or PI3-kinase signaling pathway is sufficient to protect SHSY5Y cells against rotenone-induced apoptosis. SH-SY5Y cells were transfected with $1 \mu \mathrm{g}$ of plasmid DNA encoding caMKK1, p110*, or both. All cells were cotransfected with $0.5 \mu \mathrm{g}$ of plasmid DNA encoding eGFP as a marker to identify transfected cells. Vector plasmid DNA was used as a control (C) and to supplement total amount of plasmid DNA in each $35 \mathrm{~mm}$ plate to 2.5 $\mu \mathrm{g}$. Two days after transfection, cells were treated with $50 \mathrm{~nm}$ rotenone or vehicle control (V) for $24 \mathrm{~h}$, and apoptosis in transfected cells (eGFP ${ }^{+}$) was analyzed. Data are from two independent experiments with triplicate determinations. At least 1200 transfected cells were counted for each data point. Error bars are SEM. ${ }^{*} p<0.05,{ }^{* *} p<0.01,{ }^{* * *} p<0.001$ (ANOVA) compared with control-transfected, rotenone-treated group.

Cooper, 1995), and U0126, an inhibitor of MKK1/2 (Favata et al., 1998), to block bFGF activation of PI3-kinase or ERK1/2, respectively. Pretreatment of SH-SY5Y cells with U0126 inhibited bFGF-induced phosphorylation of ERK1/2 but not Akt, whereas LY294002 blocked phosphorylation of Akt but not ERK1/2 (Fig. $3 B$ ). These results validate the specificity of these inhibitors for these signaling pathways in SH-SY5Y cells. Application of U0126 or LY294002 significantly reversed bFGF protection against rotenone (Fig. $3 C,{ }^{* *} p<0.001$ and ${ }^{* *} p<0.01$, respectively). Pretreatment with both inhibitors was even more effective and completely abrogated the protective effect of bFGF. These results indicate that $\mathrm{bFGF}$ protection against rotenone is mediated by activation of ERK1/2 and PI3-kinase signaling pathways.

Direct activation of ERK1/2 or PI3-kinase is sufficient to protect $\mathrm{SH}-\mathrm{SY} 5 \mathrm{Y}$ cells against rotenone

Is ectopic activation of ERK1/2 or PI3-kinase sufficient to protect against rotenone? To address this issue, $\mathrm{SH}-\mathrm{SY} 5 \mathrm{Y}$ cells were transiently transfected with plasmid DNA encoding caMKK1 (Mansour et al., 1994) to selectively activate endogenous ERK1/2. To directly activate PI3-kinase signaling, cells were transiently transfected with $\mathrm{p} 110^{\star}$, which selectively activates endogenous Akt (Hu et al., 1995). Expression of caMKK1 or p110* alone significantly inhibited rotenone-induced apoptosis (Fig. $4,{ }^{* *} p<0.01$, $\left.{ }^{* * *} p<0.001\right)$. Expression of both constructs was more effective than either construct alone and provided complete protection against rotenone. Collectively, these data indicate that both ERK1/2 and PI3-kinase signaling pathways contribute to bFGF protection against rotenone in SH-SY5Y cells. Furthermore, the protection afforded by these two pathways is not redundant and 


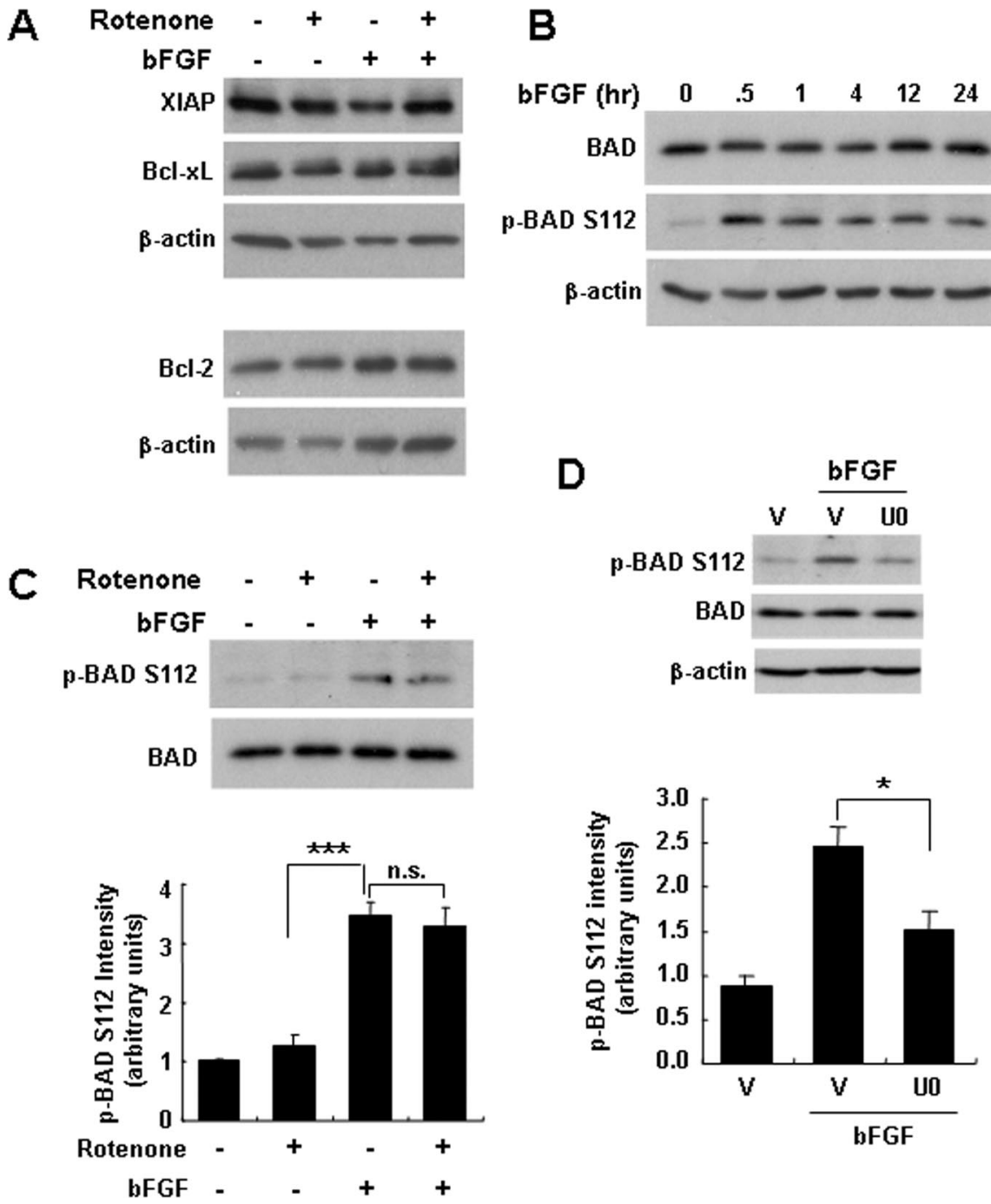

Figure 5. bFGF activation of ERK1/2 signaling induces BAD phosphorylation at serine 112 in SH-SY5Y cells. $A$, Rotenone or bFGF does not change protein expression of XIAP, BCl-XL, or BCl-2. SH-SY5Y cells were treated with rotenone $(50 \mathrm{~nm}), \mathrm{bFGF}(10 \mathrm{ng} / \mathrm{ml})$, or the two together for $24 \mathrm{~h}$, and cell lysates were analyzed for XIAP, BCl-XL, or BCl-2 expression by Western blotting. Immunoblots were reprobed with an anti- $\beta$-actin antibody as a loading control. $\boldsymbol{B}, \mathrm{bFGF}$ does not change BAD protein expression but induces a prolonged phosphorylation of BAD at Ser112.SH-SY5Y cells were stimulated with $10 \mathrm{ng} / \mathrm{ml} \mathrm{bFGF}$ for $0-24 \mathrm{~h}$, and cell lysates were analyzed by immunoblotting with antibodies recognizing total BAD or BAD phosphorylated at Ser112 (p-BAD S112). C, bFGF induces BAD phosphorylation at Ser112 even in the presence of rotenone. Cells were treated with bFGF and rotenone as in $\boldsymbol{A}$. $\boldsymbol{D}$, bFGF phosphorylation of BAD at serine 112 is mediated via the ERK1/2 pathway. Cells were pretreated for $1 \mathrm{~h}$ with $10 \mu \mathrm{m} U 0126$ (U0) or vehicle control (V), followed by $1 \mathrm{~h}$ treatment with $10 \mathrm{ng} / \mathrm{ml} \mathrm{bFGF.} \mathrm{Immunoblots} \mathrm{are} \mathrm{representative} \mathrm{of} \mathrm{at} \mathrm{least} \mathrm{three}$ independent experiments. Relative BAD phosphorylation in $\boldsymbol{C}$ and $\boldsymbol{D}$ were obtained from four to five Western blots and normalized to total BAD protein levels. Error bars are SEM. ${ }^{*} p<0.05,{ }^{* * *} p<0.001$ (ANOVA). ns, Not statistically significant.
1999; Riccio et al., 1999; Borner, 2003). Consequently, we examined the effect of rotenone and bFGF treatment on the expression of pro-survival proteins, including XIAP, Bcl-2, and Bcl-xL, and the proapoptotic $\mathrm{BAD}$ protein (Fig. $5 A, B$ ). Treatment of rotenone did not cause any change in the expression of these proteins, consistent with a recent report (Watabe and Nakaki, 2004). Addition of bFGF, either alone or with rotenone, also did not affect protein expression of XIAP, Bcl-2, $\mathrm{Bcl}-\mathrm{xL}$, or BAD.

In addition to regulation of gene expression, trophic factors may promote neuronal survival by phosphorylating and inactivating proapoptotic proteins (Zha et al., 1996; Datta et al., 1997; del Peso et al., 1997). For example, BAD is phosphorylated by several kinases at distinct sites, which inactivates its proapoptotic activity. These include phosphorylation at Ser136 by Akt (Wang et al., 1996; Zha et al., 1996; Datta et al., 1997; del Peso et al., 1997), and phosphorylation at Ser112 by p90 ribosomal S6 kinase ( $\left.\mathrm{p} 90^{\mathrm{RSK}}\right)$, a downstream target of ERK1/2 (Bonni et al., 1999; Fang et al., 1999). Because the commercially available antibodies against BAD phosphorylated at Ser136 only recognize ectopically overexpressed but not endogenous $\mathrm{BAD}$ in our system, we were unable to detect endogenous BAD phosphorylated at serine 136 in SH-SY5Y cells (data not shown). Others also reported difficulty in detecting Ser 136 phosphorylation of endogenous BAD (Wang et al., 2005b). However, bFGF induced BAD phosphorylation at serine 112 (Fig. 5B), which persisted even in the presence of rotenone (Fig. 5C). Pretreatment with U0126 to inhibit ERK1/2 signaling abrogated bFGF induction of $\mathrm{BAD}$ phosphorylation at Ser112 (Fig. $5 D,{ }^{*} p<0.05$ ). These data suggest that bFGF may protect against rotenone-induced apoptosis by activating of ERK1/2, which in turn phosphorylates and inactivates BAD. may be attributable to independent, downstream neuroprotective mechanisms.

\section{bFGF induces BAD phosphorylation at serine 112 through activation of ERK1/2}

Rotenone induces apoptosis in SH-SY5Y cells through a caspase 9/3-dependent, mitochondrial pathway (Newhouse et al., 2004; Li et al., 2005). The mitochondrial apoptotic pathway is often regulated by $\mathrm{Bcl}-2$ family proteins that modulate the membrane potential and function of mitochondria. For example, cell death signals can induce apoptosis by decreasing the expression of prosurvival Bcl-2 family proteins or increasing the expression of prodeath Bcl-2 family proteins. In contrast, trophic factors function in an opposite manner to promote cell survival (Bonni et al.,
BAD plays an essential role in rotenone-induced apoptosis If ERK1/2 phosphorylation of BAD plays a critical role in bFGF protection against rotenone, BAD may be obligatory for rotenone-mediated apoptosis and ablation of $\mathrm{BAD}$ expression may render SH-SY5Y cells resistant to rotenone. To address this issue, we introduced an siRNA specific to human BAD (siBAD) into $\mathrm{SH}-\mathrm{SY} 5 \mathrm{Y}$ cells to silence BAD protein expression. Two days after transfection, cell lysates were prepared for analysis of BAD protein. Transfection of siBAD, but not a nonspecific RNA oligomer control, reduced BAD protein levels by $51 \%$ in $2 \mathrm{~d}$ (Fig. $6 A)$. Importantly, rotenone-induced apoptosis was reduced to basal levels $(4.4 \%)$ in cells transfected with siBAD (Fig. $6 \mathrm{~B}$ ); there was $3 \%$ apoptosis in the presence of both siBAD and bFGF. The difference in the levels of apoptosis in the presence of siBAD 

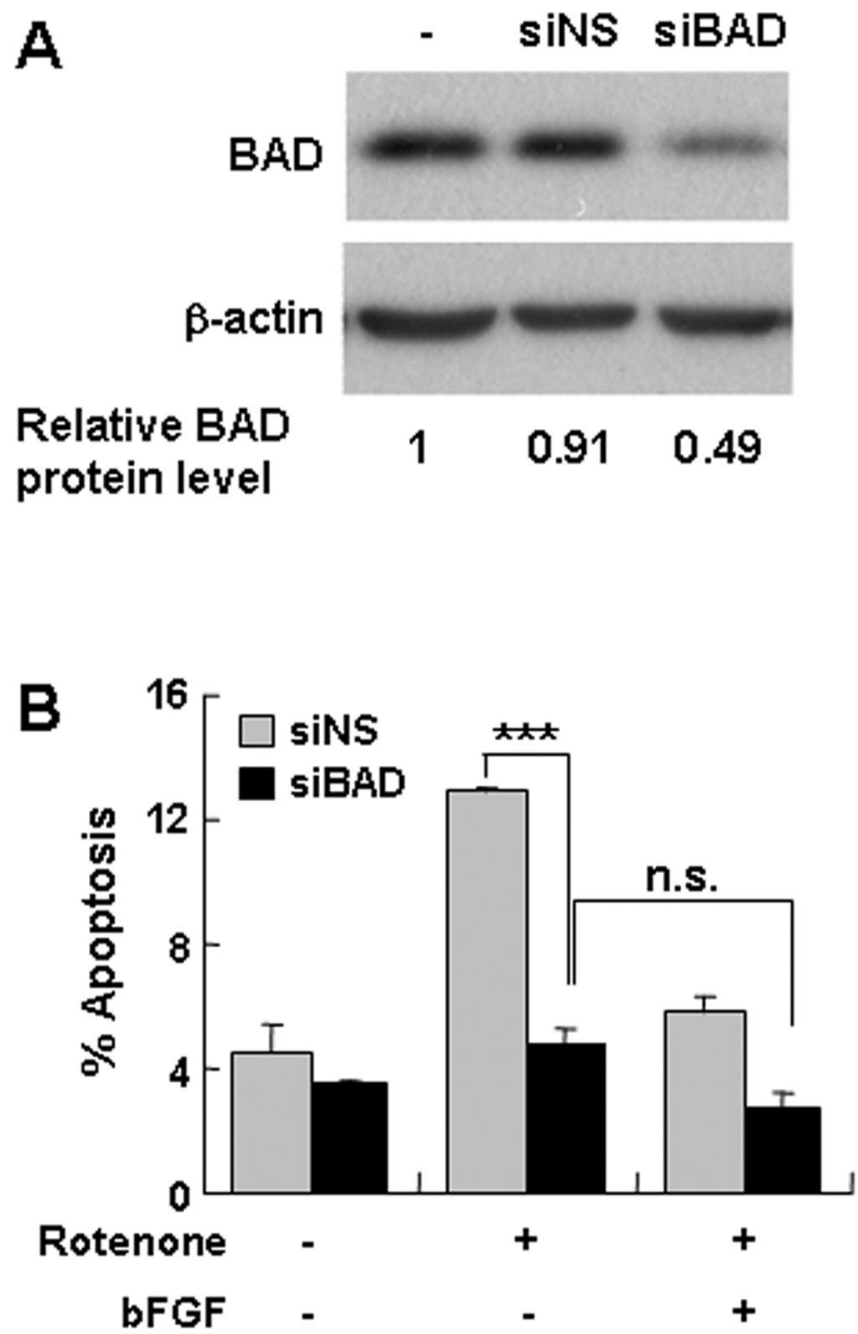

Figure 6. siRNA knockdown of BAD expression abolishes rotenone-induced apoptosis in SH-SY5Y cells. A, Transfection of siBAD, but not siNS, reduces BAD protein expression. SH-SY5Y cells were transfected with a $100 \mathrm{~nm}$ concentration of an siRNA specific to human BAD or a FITC-labeled doubled-stranded RNA oligomer control. BAD protein expression was analyzed $2 \mathrm{~d}$ later by Western blotting. The relative expression levels of BAD were normalized to the loading control $\beta$-actin. $\boldsymbol{B}$, Reduced BAD expression renders SH-SY5Y cells resistant to rotenone. Cells were transfected with siRNA as in $\boldsymbol{A}$. Cells were also cotransfected with plasmid DNA encoding eGFP to label transfected cells. Two days after transfection, cells were pretreated with $10 \mathrm{ng} / \mathrm{ml}$ bFGF or vehicle control for $1 \mathrm{~h}$, followed by $50 \mathrm{~nm}$ rotenone or vehicle control for $24 \mathrm{~h}$. Apoptosis were scored in eGFP-positive cell population. Data are representative of three independent experiments. At least 600 transfected cells were counted in each data point. Error bars are SEM. ${ }^{* * *} p<0.001$; ns, not significant (ANOVA).

alone or together with bFGF was statistically insignificant $(p=$ 0.099).

Because $\mathrm{BAD}$ regulates mitochondrial function and induces cell death through the mitochondrial-mediated, intrinsic cell death pathway, we determined whether rotenone induces release of cell death factors from mitochondria. AIF is released from mitochondria and translocates to the nucleus in response to death stimuli, including glutamate and 1-methyl-4phenylpyridinium toxicity in neurons (Chu et al., 2005; Culmsee et al., 2005). SH-SY5Y cells were treated with rotenone in the presence or absence of bFGF and stained with an anti-AIF antibody. Nuclear morphology was revealed by Hoechst staining. In control or bFGF-treated cells, AIF staining was only found in the cytoplasm (Fig. 7). AIF translocated into the nucleus during rotenone treatment, a process that was blocked by bFGF. Together, data in Figures 6 and 7 implicate BAD and mitochondrial dysfunction in rotenone-induced apoptosis. Furthermore, BAD phosphorylation and inactivation may underlie bFGF neuroprotection.

\section{Rotenone induces selective degeneration of $\mathrm{TH}^{+}$}

dopaminergic neurons in primary mesencephalic cultures

To determine whether the apoptotic mechanisms described above are applicable to rotenone-induced cell death in primary cultured dopaminergic neurons, we examined primary neurons from E14 rat mesencephalon. Dopaminergic neurons were identified by immunostaining for TH (Fig. $8 \mathrm{~A}$ ). Treatment with as little as $1 \mathrm{nM}$ rotenone for $24 \mathrm{~h}$ caused a $40 \%$ reduction in the number of surviving $\mathrm{TH}^{+}$cells ${ }^{* *} p<0.01$; $\left.{ }^{* * *} p<0.001\right)$, whereas $5 \mathrm{~nm}$ rotenone almost completely killed all $\mathrm{TH}^{+}$neurons (Fig. $8 \mathrm{~B}$ ). Apoptosis in dopaminergic neurons was confirmed by positive TUNEL and active caspase- 3 staining in $\mathrm{TH}^{+}$cells after rotenone treatment (Fig. $8 \mathrm{C}$ ). Furthermore, rotenone induced nuclear translocation of AIF (see Fig. 10). These results confirm that the loss of $\mathrm{TH}^{+}$cells reflects apoptosis rather than downregulation of tyrosine hydroxylase expression.

In contrast to the loss of dopaminergic neurons, GABAergic neurons, which are abundant in the primary cultures, were not sensitive to rotenone under the same conditions. There was no significant loss of cells staining positive for GABA (Fig. 9A), and $<4 \%$ of $\mathrm{GABA}^{+}$cells stained positive for TUNEL (Fig. $9 B$ and data not shown). Similarly, 1-5 nm rotenone did not cause a significant increase in apoptotic nuclei (Fig. 9C) or a significant loss of cells in the entire population (Fig. 9D). Thus, $\mathrm{TH}^{+}$dopaminergic neurons are much more sensitive to rotenone toxicity than $\mathrm{TH}^{-}$cells in the same culture.

bFGF protects against rotenone-induced cell death of primary dopaminergic neurons via activation of ERK1/2 and

PI3-kinase pathways

To determine whether rotenone-induced apoptosis in primary cultured dopaminergic neurons is inhibited by bFGF, E14 mesencephalic cultures were pretreated with $10 \mathrm{ng} / \mathrm{ml}$ bFGF $1 \mathrm{~h}$ before addition of rotenone. bFGF blocked rotenone-induced AIF nuclear translocation (Fig. 10). It also provided significant protection against rotenone-induced loss of $\mathrm{TH}^{+}$neurons (Fig. $11 \mathrm{~A}$, $\left.{ }^{* *} p<0.01,{ }^{* *} p<0.001\right)$. Preincubation with U0126 or LY294002 completely abrogated bFGF protection (Fig. $11 B$, $\left.{ }^{* *} p<0.001\right)$. These data suggest that both ERK1/2 and PI3kinase signaling pathways are required for bFGF protection against rotenone in primary cultured dopaminergic neurons. The two pathways may be redundant and may converge on a common regulatory site.

\section{Discussion}

The objectives of this study were to further characterize molecular mechanisms underlying rotenone-induced dopaminergic cell death and to identify neuroprotective mechanisms against this toxicity. We identified BAD as a critical mediator of rotenoneinduced cell death in SH-SY5Y cells. Furthermore, we discovered that bFGF protects against rotenone-induced cell death in both SH-SY5Y cells and primary cultured dopaminergic neurons. Finally, bFGF neuroprotection requires activation of ERK1/2 and PI3-kinase signaling pathways.

Although the etiology of idiopathic Parkinson's disease remains elusive, increased disease risk is mostly likely associated with multiple environmental factors (Dauer and Przedborski, 2003; Dawson and Dawson, 2003). Therefore, it is important to 

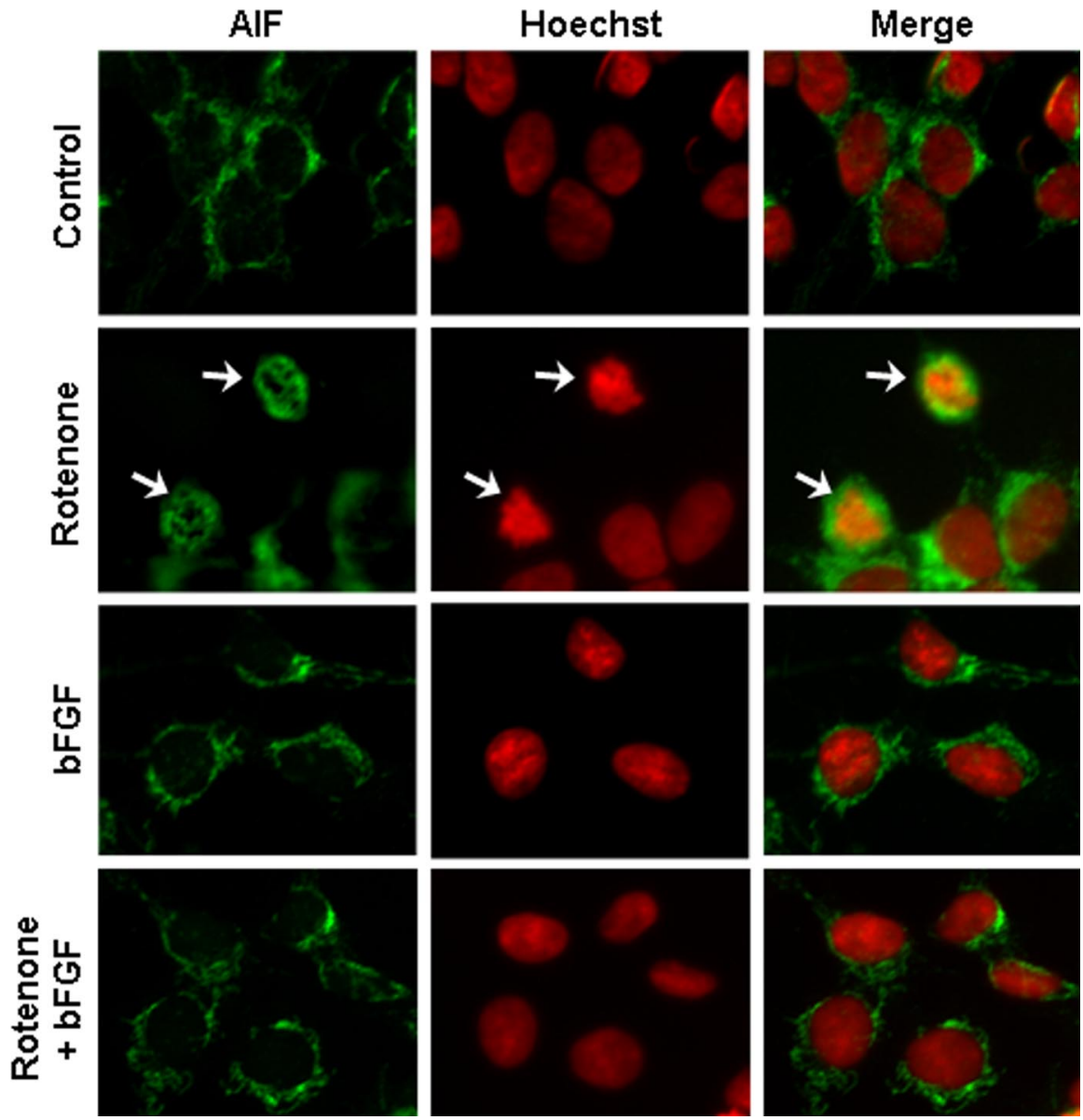

Figure 7. bFGF blocks rotenone-induced AIF nuclear translocation in SH-SY5Y cells. SH-SY5Y cells were pretreated with 10 $\mathrm{ng} / \mathrm{ml}$ bFGF or vehicle control for $1 \mathrm{~h}$, followed by 0 or $100 \mathrm{~nm}$ rotenone for $12 \mathrm{~h}$. Cells were stained with an anti-AIF antibody and Hoechst. Data are deconvolution confocal images and representative of two independent experiments with triplicate determinations. Hoechst staining was pseudocolored to red to better visualize colocalization with AIF. Arrows point to cells with nuclear AIF staining.

examine multiple Parkinson's disease models to study mechanisms of neuronal cell death. Cell death mechanisms as well as neuroprotective mechanisms common to different Parkinson's disease models may identify drug targets for Parkinson's disease treatment. The neurotoxicants MPTP and 6-hydroxy-dopamine (6-OHDA) have been used extensively both in vitro and in vivo as models for Parkinson's disease. Recent studies demonstrated that chronic administration of rotenone to rats produces many features of Parkinson's disease, including nigrostriatal degeneration and aggregation of $\alpha$-synuclein in the brain (Betarbet et al., 2000; Sherer et al., 2003a). Chronic exposure of Drosophila melanogaster to rotenone also models sporadic Parkinson's disease (Coulom and Birman, 2004). However, other studies have questioned whether rotenone-induced motor abnormalities result from a loss of dopaminergic neurons (Perier et al., 2003; Fleming et al., 2004; Lapointe et al., 2004) and challenged the idea that rotenone induces selective loss of dopaminergic neurons (Hoglinger et al., 2003). In this study, we showed that, at low concentrations of rotenone (1-5 nM), dopaminergic neurons were much more sensitive to rotenone-induced cell loss than the general cellular population in E14 mesencephalic primary neuron cultures. Therefore, our data support the notion that exposure to low concentrations of rotenone causes selective loss of dopaminergic neurons and may be a useful cellular model to study Parkinson's disease in vitro.
Although rotenone inhibits mitochondrial complex I, its effect on cell death is unlikely a direct result of reduced ATP production and bioenergy failure (Sherer et al., 2003b). Furthermore, $\left[{ }^{3} \mathrm{H}\right]$ dihydrorotenone binding to mitochondrial complex $\mathrm{I}$ in the rodent brain is saturable and has a $K_{\mathrm{D}}$ of $15-55 \mathrm{nM}$; this binding is inhibited by rotenone with an $\mathrm{IC}_{50}$ of $8-20 \mathrm{nM}$ (Higgins and Greenamyre, 1996). These concentrations are higher than the $5 \mathrm{~nm}$ rotenone, which caused an almost complete loss of $\mathrm{TH}^{+}$dopaminergic neurons in culture. Thus, our data suggest the interesting possibility that rotenoneinduced cell death may include other mechanisms in addition to mitochondrial complex I inhibition.

Signaling pathways that regulate rotenone-induced dopaminergic cell death are beginning to be defined. Our previous studies identified stress-activated MAP kinases c-Jun N-terminal protein kinase and p38 as key contributors (Newhouse et al., 2004). Rotenone-induced dopaminergic cell death requires activation of caspases 9/3 (Kitamura et al., 2002; Ahmadi et al., 2003; Newhouse et al., 2004; Li et al., 2005). Here, we discovered that rotenone induces nuclear translocation of AIF from mitochondria in both SH-SY5Y and $\mathrm{TH}^{+}$cells, suggesting that caspaseindependent apoptosis may also underlie rotenone neurotoxicity. Furthermore, rotenone-induced dopaminergic cell death in SH-SY5Y cells is completely abrogated by siRNA silencing of BAD expression, a member of the proapoptotic family of $\mathrm{Bcl}-2$ proteins that regulates mitochondria function and the intrinsic cell death pathway. These results suggest that rotenoneinduced dopaminergic cell death requires the mitochondrialmediated, intrinsic cell death pathway.

By the time Parkinson's disease is clinically diagnosed in human patients, at least $50-70 \%$ of the dopaminergic neurons are already lost (Agid et al., 1990; Anglade et al., 1995). Current therapies for Parkinson's disease mostly provide symptomatic relief but do not slow disease progression. Although pituitary adenylate cyclase-activating polypeptide and angiotensin II have been reported to protect against rotenone toxicity (Grammatopoulos et al., 2005; Wang et al., 2005a), the effect of growth factors in the rotenone model of Parkinson's disease had not been examined until our study. Here we demonstrate that bFGF, EGF, and GDNF promote survival of SH-SY5Y cells treated with rotenone, with bFGF offering the greatest level of protection. Both bFGF and its receptor are expressed in the neurons of SNpc (Wanaka et al., 1990; Bean et al., 1991; Wanaka et al., 1991; Belluardo et al., 1997; Walker et al., 1998), and we discovered that bFGF protects primary cultured dopaminergic neurons against rotenone. In the Parkinsonian brain, there is substantial loss of bFGFimmunoreactive neurons in the SNpc (Tooyama et al., 1993; Tooyama et al., 1994). Both intrastriatal injection and intraventricular infusion of bFGF protect mice in an MPTP model of Parkinson's disease (Otto and Unsicker, 1990; Chadi et al., 1993; 
Otto and Unsicker, 1993). bFGF also increases dopaminergic graft survival and function in a rat model of Parkinson's disease (Takayama et al., 1995). Fibroblasts that have been genetically engineered to produce bFGF and implanted into the striatum attenuate damage caused by intrastriatal injection of 6-OHDA (Shults et al., 2000). Together, these studies, with our data, suggest that bFGF may be useful in the treatment of Parkinson's disease.

We also investigated signaling pathways mediating bFGF neuroprotection. bFGF induced phosphorylation and activation of ERK1/2 and PI3-kinase signaling pathways. Both ERK1/2 and PI3-kinase signaling pathways have been implicated in protecting various types of neurons against different injuries (Xia et al., 1995; Dudek et al., 1997; Hetman et al., 1999; Hetman and Xia, 2000; Chang et al., 2004). However, their involvement in neuroprotection in Parkinson's disease models is essentially uncharacterized, although recent reports implicated them in GDNF or NGF protection against 6-OHDA (Salinas et al., 2003; Ugarte et al., 2003). In this study, we demonstrate that ectopic activation of either ERK1/2 or PI3-kinase pathway is sufficient to protect $\mathrm{SH}-\mathrm{SY} 5 \mathrm{Y}$ cells against rotenone. Pharmacological inhibition of either pathway blocked bFGF protection in both SH-SY5Y cells and primary cultured dopaminergic neurons. Although both ERK1/2 and PI3-kinase signaling are required for bFGF protection against rotenone in SH-SY5Y cells and in primary cultured dopaminergic neuron, the two pathways seem to be redundant in primary neurons but independent in SH-SY5Y cells. This may reflect differences in cell types. For example, although there is no crosstalk between the two signaling pathways in SH-SY5Y cells (Fig. 3B), some isoforms of neuronal PI3-kinase activate the ERK1/2 pathway (Lopez-Ilasaca et al., 1997). Therefore, it is possible that PI3kinase and ERK1/2 protect SH-SY5Y cells against rotenone by phosphorylating $\mathrm{BAD}$ at serine 136 and serine 112, respectively. However, the neuroprotective effect of PI3-kinase in primary cultured dopaminergic neurons may be mediated through ERK1/2, which explains why either U0126 or LY294002 treatment completely abrogates bFGF protection against rotenone in these neurons. Regardless, our data identify activation of ERK1/2 and PI3-kinase signaling pathways as novel targets to attenuate neuronal loss in the rotenone model of Parkinson's disease. These mechanisms may also apply to other Parkinson's disease models.

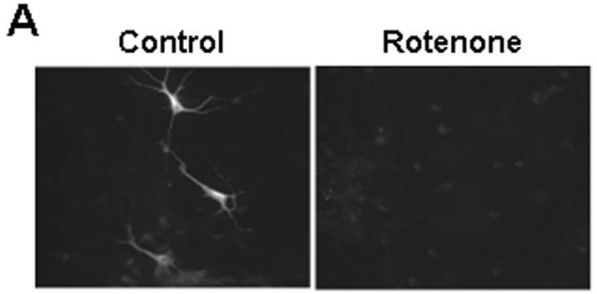

TH staining
B

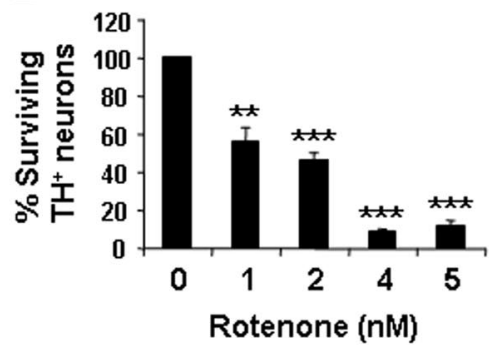

C

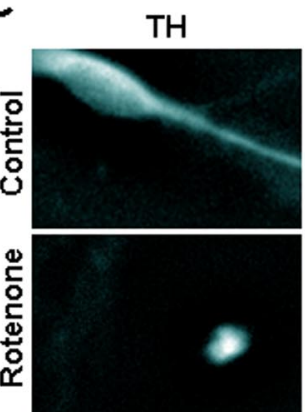

Hoechst
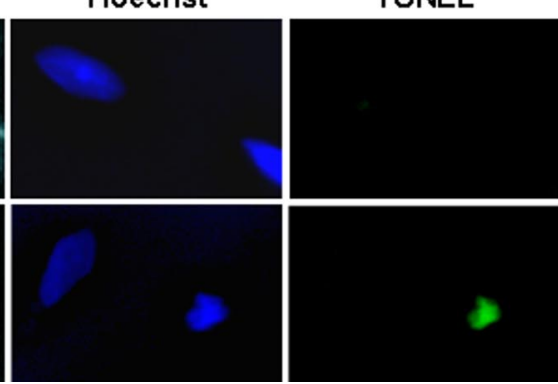

Active caspase-3

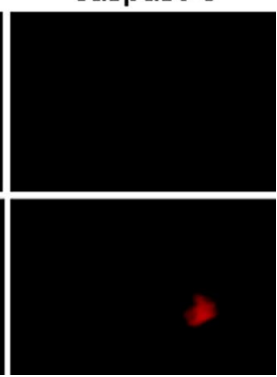

Figure 8. Rotenone induces dopaminergic neuron apoptosis in E14 ventral mesencephalic primary cultures. Primary ventral mesencephalic cultures were prepared from $\mathrm{E} 14$ rats and treated with rotenone for $24 \mathrm{~h}$. $A$, Representative photomicrographs of cells treated with $5 \mathrm{~nm}$ rotenone or vehicle control for $24 \mathrm{~h}$ and immunostained for $\mathrm{TH}$, a marker for dopaminergic neurons. $\boldsymbol{B}$, Rotenone induces a dose-dependent cell loss of $\mathrm{TH}^{+}$neurons. All $\mathrm{TH}^{+}$cells on each coverslip were counted. Vehicle control represents $100 \%$ survival, which has $\sim 100 \mathrm{TH}^{+}$neurons per coverslip. C, Representative deconvolution confocal photomicrographs of cell treated with $2 \mathrm{~nm}$ rotenone or vehicle control for $18 \mathrm{~h}$. Cells were TUNEL labeled, followed by immunostaining for active caspase- 3 and TH. Data are representative of at least two independent experiments with duplicate determinations. Error bars are SEM. ${ }^{* *} p<0.01,{ }^{* * *} p<0.001$ (ANOVA) compared with vehicle control-treated group.

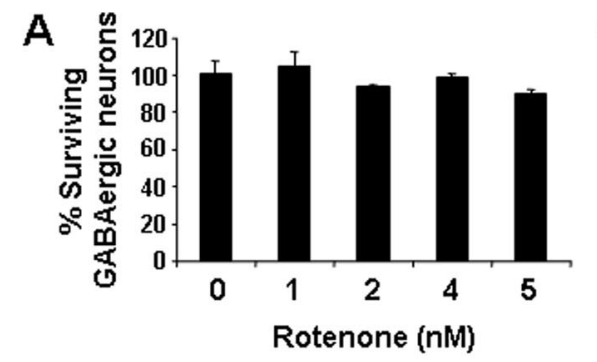

B

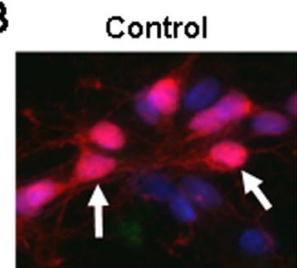

GABAHoechstTUNEL

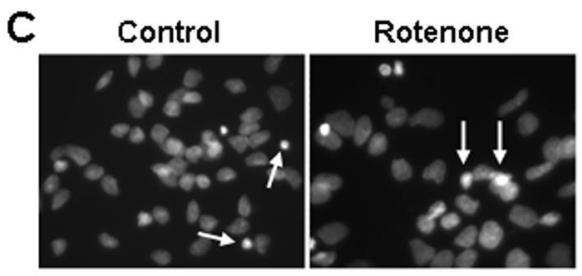

Hoechst staining of nuclei

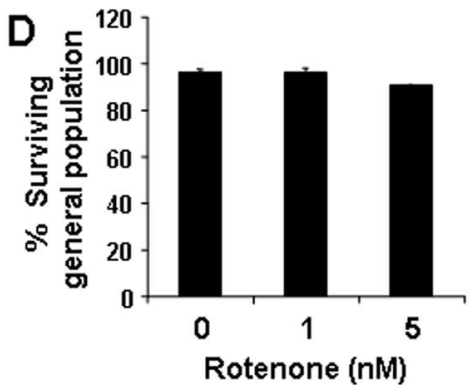

Figure 9. Rotenone does not induce cell loss of GABAergic neurons or the general population. Primary ventral mesencephalic cultures were prepared from $\mathrm{E} 14$ rats and treated with $0-5 \mathrm{~nm}$ rotenone for $24 \mathrm{~h}$. $A$, Cells were immunostained for GABA, and the number of GABA ${ }^{+}$cells in 10 randomly selected fields was counted. Vehicle control represents $100 \%$ survival. $\boldsymbol{B}$, Representative photomicrographs of cells treated with rotenone or vehicle control for $24 \mathrm{~h}$ and stained for TUNEL (green), GABA (red), and Hoechst (blue). Arrows point to GABA ${ }^{+}$neurons that are negative for TUNEL. C, Representative photomicrographs of nuclear morphology of the entire population, revealed by Hoechst staining. Cells were treated with rotenone as in $\boldsymbol{A}$. Arrows point to condensed or fragmented nuclei, characteristic of apoptosis. $\boldsymbol{D}$, Rotenone treatment did not affect survival of the general population based on nuclear morphological changes revealed by Hoechst staining as in $\boldsymbol{C}$. Data are representative of two $(\boldsymbol{A})$ or three $(\boldsymbol{D})$ independent experiments with duplicate determinations. At least 2000 cells were counted for each condition. 

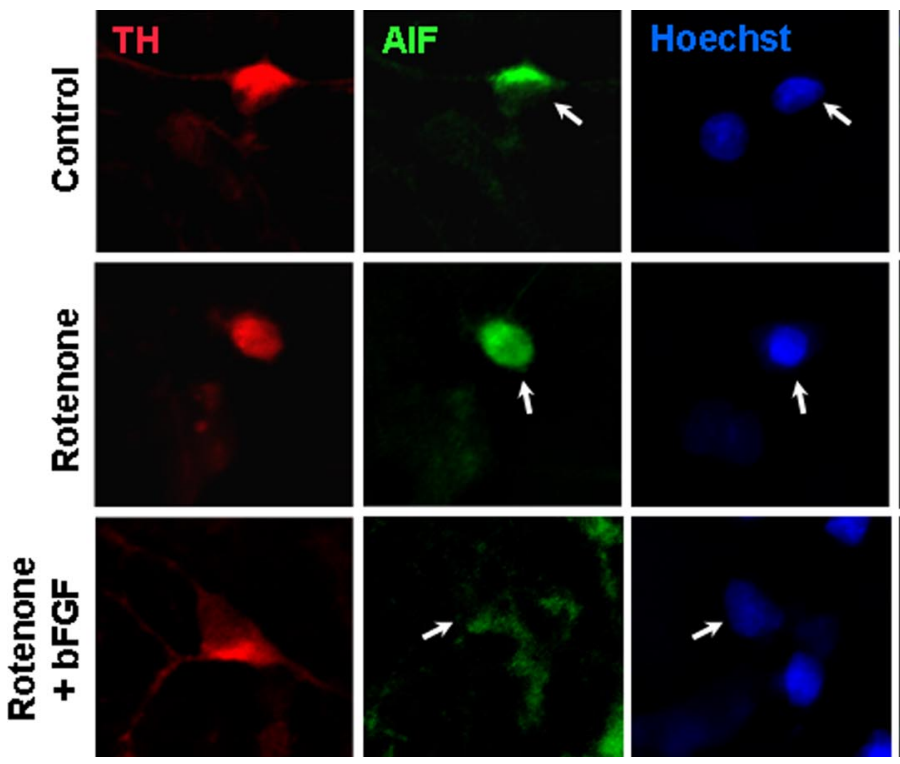

Figure 10. bFGF blocks rotenone-induced AIF nuclear translocation in primary cultured dopaminergic cells. Primary ventral mesencephalic cultures were pretreated with $10 \mathrm{ng} / \mathrm{ml} \mathrm{bFGF}$ for $1 \mathrm{~h}$ before $2 \mathrm{~nm}$ rotenone treatment for $12 \mathrm{~h}$ when indicated. Images are representative deconvolution confocal photomicrographs of cells stained for TH (red), AIF (green), and Hoechst (blue). Arrows point to the nuclei of $\mathrm{TH}^{+}$neurons. Data are representatives of two independent experiments with triplicate determinations.
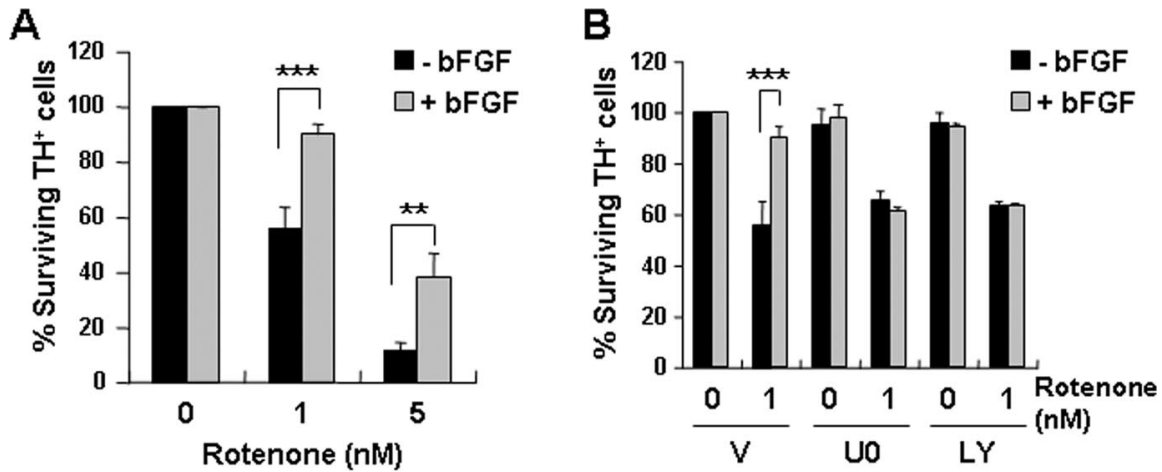

Figure 11. bFGF protects primary dopaminergic neurons against rotenone-induced cell death via activation of ERK1/2 and $\mathrm{PI3}$-kinase pathways. $\boldsymbol{A}$, bFGF reduces rotenone-induced loss of $\mathrm{TH}^{+}$dopaminergic neurons. Primary ventral mesencephalic cultures were pretreated with $10 \mathrm{ng} / \mathrm{ml} \mathrm{bFGF}$ for $1 \mathrm{~h}$, followed by 1-5 nm rotenone treatment for $24 \mathrm{~h}$. Data were from two independent experiments with duplicate determinations. $\boldsymbol{B}, \mathrm{bFGF}$ protection against rotenone is reversed by pharmacological inhibition of ERK1/2 or PI3-kinase pathways. Primary ventral mesencephalic cultures were pretreated with bFGF for $1 \mathrm{~h}$, followed by a $24 \mathrm{~h}$ treatment with rotenone, $10 \mu \mathrm{m}$ U0126 (U0), $10 \mu \mathrm{m} \mathrm{LY294002} \mathrm{(LY),} \mathrm{or} \mathrm{vehicle} \mathrm{control} \mathrm{(V)} \mathrm{as} \mathrm{indicated.} \mathrm{All} \mathrm{TH}{ }^{+}$cells on each coverslip were counted. Vehicle control represents $100 \%$ survival. Data are representative of two independent experiments with triplicate determinations. Error bars are SEM. ${ }^{* *} p<0.01,{ }^{* * *} p<0.001$ (ANOVA).

A variety of molecules key to cell death regulation are regulated by trophic factors at the transcriptional or posttranslational level (Borner, 2003; Prunell and Troy, 2004). For instance, bFGF protects lung cancer cells from chemotherapeutic drugs via ERK1/2 activation and subsequent induction of expression of $\mathrm{XIAP}$, as well as phosphorylation of Bcl-2 and Bcl-xL (Pardo et al., 2002, 2003). We examined protein levels of XIAP, Bcl-2, and $\mathrm{Bcl}-\mathrm{xL}$ in SH-SY5Y cells after treatment with rotenone, bFGF, or the two together and found no change in their expression. Similarly, rotenone or bFGF did not cause any change in the expression of $\alpha$-synuclein or parkin (data not shown), proteins whose misregulation has been implicated in Parkinson's disease (Chung et al., 2001; Dawson and Dawson, 2003).
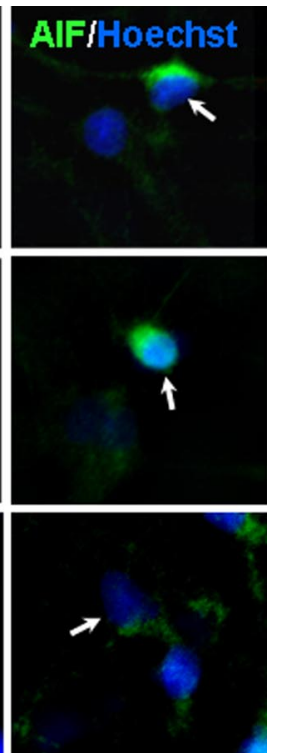

BAD promotes apoptosis by forming heterodimers with Bcl-xL or Bcl-2 (Zha et al., 1996; Fang et al., 1999). The phosphorylation status of BAD influences its ability to interact with $\mathrm{Bcl}-2$ and $\mathrm{Bcl}-\mathrm{xL}$. Akt phosphorylates $\mathrm{BAD}$ at serine 136 (del Peso et al., 1997), whereas $\mathrm{p} 90^{\mathrm{RSK}}$, a downstream target of ERK1/2, phosphorylates BAD at serine 112 (Bonni et al., 1999; Fang et al., 1999). Phosphorylation at either site induces $\mathrm{BAD}$ association with 14-3-3 protein, preventing BAD from dimerizing with $\mathrm{Bcl}-2$ or $\mathrm{Bcl}-\mathrm{xL}$, thus inactivating the proapoptotic activity of BAD (Zha et al., 1996). Although we were unable to detect endogenous BAD in $\mathrm{SH}$ SY5Y phosphorylated at serine 136, we demonstrated that bFGF induces a sustained phosphorylation of $\mathrm{BAD}$ protein at Ser112, even in the presence of rotenone. This phosphorylation was prevented by pharmacological inhibition of ERK1/2 but not PI3-kinase (Fig. 5 and data not shown). Together with the data that siRNA reduction of BAD expression abrogates rotenone-induced cell death, our results suggest that BAD phosphorylation at serine 112 induced by ERK1/2 activation may play a critical role in bFGF protection against rotenone.

In conclusion, our results help to better characterize rotenone as an emerging model to study pathogenesis of Parkinson's disease. We identify BAD as a key mediator of rotenone-induced dopaminergic cell death. Furthermore, bFGF and its activation of ERK1/2 and PI3-kinase signaling may be useful targets for preventing Parkinson's disease progression.

\section{References}

Agid Y, Ruberg M, Raisman-Vozari R, Hirsch EC, Javoy-Agid F (1990) The biochemistry of Parkinson's disease. In: Parkinson's disease (Stern G, ed), pp 99-125. London: Chapman and Hall.

Ahmadi FA, Linseman DA, Grammatopoulos TN, Jones SM, Bouchard RJ, Freed CR, Heidenreich KA, Zawada WM (2003) The pesticide rotenone induces caspase-3-mediated apoptosis in ventral mesencephalic dopaminergic neurons. J Neurochem 87:914-921.

Anglade P, Tsuji S, Javoy-Agid F, Agid Y, Hirsch EC (1995) Plasticity of nerve afferents to nigrostriatal neurons in Parkinson's disease. Ann Neurol 37:265-272.

Ballard PA, Tetrud JW, Langston JW (1985) Permanent human parkinsonism due to 1-methyl-4-phenyl-1,2,3,6-tetrahydropyridine (MPTP): seven cases. Neurology 35:949-956.

Bean AJ, Elde R, Cao YH, Oellig C, Tamminga C, Goldstein M, Pettersson RF, Hokfelt T (1991) Expression of acidic and basic fibroblast growth factors in the substantia nigra of rat, monkey, and human. Proc Natl Acad Sci USA 88:10237-10241.

Belluardo N, Wu G, Mudo G, Hansson AC, Pettersson R, Fuxe K (1997) Comparative localization of fibroblast growth factor receptor-1, -2 , and -3 mRNAs in the rat brain: in situ hybridization analysis. J Comp Neurol 379:226-246. 
Betarbet R, Sherer TB, MacKenzie G, Garcia-Osuna M, Panov AV, Greenamyre JT (2000) Chronic systemic pesticide exposure reproduces features of Parkinson's disease. Nat Neurosci 3:1301-1306.

Bonni A, Brunet A, West AE, Datta SR, Takasu MA, Greenberg ME (1999) Cell survival promoted by the Ras-MAPK signaling pathway by transcription-dependent and -independent mechanisms. Science 286:1358-1362.

Borner C (2003) The Bcl-2 protein family: sensors and checkpoints for lifeor-death decisions. Mol Immunol 39:615-647.

Chadi G, Moller A, Rosen L, Janson AM, Agnati LA, Goldstein M, Ogren SO, Pettersson RF, Fuxe K (1993) Protective actions of human recombinant basic fibroblast growth factor on MPTP-lesioned nigrostriatal dopamine neurons after intraventricular infusion. Exp Brain Res 97:145-158.

Chang SH, Poser S, Xia Z (2004) A novel role for serum response factor in neuronal survival. J Neurosci 24:2277-2285.

Chu CT, Zhu JH, Cao G, Signore A, Wang S, Chen J (2005) Apoptosis inducing factor mediates caspase-independent 1-methyl-4-phenylpyridinium toxicity in dopaminergic cells. J Neurochem 94:1685-1695.

Chung KK, Zhang Y, Lim KL, Tanaka Y, Huang H, Gao J, Ross CA, Dawson VL, Dawson TM (2001) Parkin ubiquitinates the alpha-synucleininteracting protein, synphilin-1: implications for Lewy-body formation in Parkinson disease. Nat Med 7:1144-1150.

Coulom H, Birman S (2004) Chronic exposure to rotenone models sporadic Parkinson's disease in Drosophila melanogaster. J Neurosci 24:10993-10998.

Culmsee C, Zhu C, Landshamer S, Becattini B, Wagner E, Pellechia M, Blomgren K, Plesnila N (2005) Apoptosis-inducing factor triggered by poly(ADP-Ribose) polymerase and bid mediates neuronal cell death after oxygen-glucose deprivation and focal cerebral ischemia. J Neurosci 25:10262-10272.

Datta SR, Dudek H, Tao X, Masters S, Fu HA, Gotoh Y, Greenberg ME (1997) Akt phosphorylation of BAD couples survival signals to the cellintrinsic death machinery. Cell 91:231-241.

Dauer W, Przedborski S (2003) Parkinson's disease: mechanisms and models. Neuron 39:889-909.

Dawson TM, Dawson VL (2003) Molecular pathways of neurodegeneration in Parkinson's disease. Science 302:819-822.

del Peso L, Gonzalez-Garcia M, Page C, Herrera R, Nunez G (1997) Interleukin-3-induced phosphorylation of $\mathrm{BAD}$ through the protein kinase Akt. Science 278:687-689.

Dérijard B, Hibi M, WU IH, Barrett T, Su B, Deng T, Karin M, Davis RJ (1994) JNK1: a protein kinase stimulated by uv light and HA-ras binds to and activates the c-jun activation domain. Cell 76:1025-1037.

Desire L, Courtois Y, Jeanny JC (2000) Endogenous and exogenous fibroblast growth factor 2 support survival of chick retinal neurons by control of neuronal bcl-x(L) and bcl-2 expression through a fibroblast growth factor receptor 1- and ERK-dependent pathway. J Neurochem 75:151-163.

Dudek H, Datta SR, Franke TF, Birnbaum MJ, Yao RJ, Cooper GM, Segal RA, Kaplan DR, Greenberg ME (1997) Regulation of neuronal survival by the serine-threonine protein kinase Akt. Science 275:661-665.

Fang X, Yu S, Eder A, Mao M, Bast Jr RC, Boyd D, Mills GB (1999) Regulation of $\mathrm{BAD}$ phosphorylation at serine 112 by the Ras-mitogen-activated protein kinase pathway. Oncogene 18:6635-6640.

Favata MF, Horiuchi KY, Manos EJ, Daulerio AJ, Stradley DA, Feeser WS, VanDyk DE, Pitts WJ, Earl RA, Hobbs F, Copeland RA, Magolda RL, Scherle PA, Trzaskos JM (1998) Identification of a novel inhibitor of mitogen-activated protein kinase kinase. J Biol Chem 273:18623-18632.

Fleming SM, Zhu C, Fernagut PO, Mehta A, DiCarlo CD, Seaman RL, Chesselet MF (2004) Behavioral and immunohistochemical effects of chronic intravenous and subcutaneous infusions of varying doses of rotenone. Exp Neurol 187:418-429.

Grammatopoulos TN, Ahmadi F, Jones SM, Fariss MW, Weyhenmeyer JA, Zawada WM (2005) Angiotensin II protects cultured midbrain dopaminergic neurons against rotenone-induced cell death. Brain Res 1045:64-71.

Hetman M, Xia Z (2000) Signaling pathways mediating anti-apoptotic action of neurotrophins. Acta Neurobiol Exp (Warsz) 60:531-545.

Hetman M, Kanning K, Cavanaugh JE, Xia Z (1999) Neuroprotection by brain-derived neurotrophic factor is mediated by extracellular-signalregulated kinase and phosphatidylinositol-3 kinase. J Biol Chem 274:22569-22580.
Higgins Jr DS, Greenamyre JT (1996) $\left[{ }^{3} \mathrm{H}\right]$ dihydrorotenone binding to NADH: ubiquinone reductase (complex I) of the electron transport chain: an autoradiographic study. J Neurosci 16:3807-3816.

Hoglinger GU, Feger J, Prigent A, Michel PP, Parain K, Champy P, Ruberg M, Oertel WH, Hirsch EC (2003) Chronic systemic complex I inhibition induces a hypokinetic multisystem degeneration in rats. J Neurochem 84:491-502.

Howells DW, Porritt MJ, Wong JY, Batchelor PE, Kalnins R, Hughes AJ, Donnan GA (2000) Reduced BDNF mRNA expression in the Parkinson's disease substantia nigra. Exp Neurol 166:127-135.

Hu Q, Klippel A, Muslin AJ, Fantl WJ, Williams LT (1995) Ras-dependent induction of cellular responses by constitutively active phosphatidylinositol-3 kinase. Science 268:100-102.

King TD, Bijur GN, Jope RS (2001) Caspase-3 activation induced by inhibition of mitochondrial complex I is facilitated by glycogen synthase kinase-3beta and attenuated by lithium. Brain Res 919:106-114.

Kitamura Y, Inden M, Miyamura A, Kakimura J, Taniguchi T, Shimohama S (2002) Possible involvement of both mitochondria- and endoplasmic reticulum-dependent caspase pathways in rotenone-induced apoptosis in human neuroblastoma SH-SY5Y cells. Neurosci Lett 333:25-28.

Langston JW, Ballard P, Tetrud JW, Irwin I (1983) Chronic Parkinsonism in humans due to a product of meperidine-analog synthesis. Science 219:979-980.

Lapointe N, St-Hilaire M, Martinoli MG, Blanchet J, Gould P, Rouillard C, Cicchetti F (2004) Rotenone induces non-specific central nervous system and systemic toxicity. FASEB J 18:717-719.

Le W, Rowe D, Xie W, Ortiz I, He Y, Appel SH (2001) Microglial activation and dopaminergic cell injury: an in vitro model relevant to Parkinson's disease. J Neurosci 21:8447-8455.

Lee HJ, Choi C, Lee SJ (2002) Membrane-bound alpha-synuclein has a high aggregation propensity and the ability to seed the aggregation of the cytosolic form. J Biol Chem 277:671-678.

Li J, Spletter ML, Johnson DA, Wright LS, Svendsen CN, Johnson JA (2005) Rotenone-induced caspase 9/3-independent and -dependent cell death in undifferentiated and differentiated human neural stem cells. J Neurochem 92:462-476.

Lopez-Ilasaca M, Crespo P, Pellici PG, Gutkind JS, Wetzker R (1997) Linkage of $\mathrm{G}$ protein-coupled receptors to the MAPK signaling pathway through Pl 3-kinase gamma. Science 275:394-397.

Mansour SJ, Matten WT, Hermann AS, Candia JM, Rong S, Fukasawa K, Vande Woude GF, Ahn NG (1994) Transformation of mammalian cells by constitutively active MAP kinase kinase. Science 265:966-970.

Mouradian MM (2002) Recent advances in the genetics and pathogenesis of Parkinson disease. Neurology 58:179-185.

Newhouse K, Hsuan SL, Chang SH, Cai B, Wang Y, Xia Z (2004) Rotenoneinduced apoptosis is mediated by $\mathrm{p} 38$ and JNK MAP kinases in human dopaminergic SH-SY5Y cells. Toxicol Sci 79:137-146.

Olanow CW, Tatton WG (1999) Etiology and pathogenesis of Parkinson's disease. Annu Rev Neurosci 22:123-144.

Otto D, Unsicker K (1990) Basic FGF reverses chemical and morphological deficits in the nigrostriatal system of MPTP-treated mice. J Neurosci 10:1912-1920.

Otto D, Unsicker K (1993) FGF-2 modulates dopamine and dopaminerelated striatal transmitter systems in the intact and MPTP-lesioned mouse. Eur J Neurosci 5:927-932.

Pardo OE, Arcaro A, Salerno G, Raguz S, Downward J, Seckl MJ (2002) Fibroblast growth factor-2 induces translational regulation of Bcl-XL and Bcl-2 via a MEK-dependent pathway: correlation with resistance to etoposide-induced apoptosis. J Biol Chem 277:12040-12046.

Pardo OE, Lesay A, Arcaro A, Lopes R, Ng BL, Warne PH, McNeish IA, Tetley TD, Lemoine NR, Mehmet H, Seckl MJ, Downward J (2003) Fibroblast growth factor 2-mediated translational control of IAPs blocks mitochondrial release of Smac/DIABLO and apoptosis in small cell lung cancer cells. Mol Cell Biol 23:7600-7610.

Perier C, Bove J, Vila M, Przedborski S (2003) The rotenone model of Parkinson's disease. Trends Neurosci 26:345-346.

Prunell GF, Troy CM (2004) Balancing neuronal death. J Neurosci Res 78:1-6.

Ramsden DB, Parsons RB, Ho SL, Waring RH (2001) The aetiology of idiopathic Parkinson's disease. Mol Pathol 54:369-380.

Riccio A, Ahn S, Davenport CM, Blendy JA, Ginty DD (1999) Mediation by 
a CREB family transcription factor of NGF-dependent survival of sympathetic neurons. Science 286:2358-2361.

Salinas M, Diaz R, Abraham NG, Ruiz de Galarreta CM, Cuadrado A (2003) Nerve growth factor protects against 6-hydroxydopamine-induced oxidative stress by increasing expression of heme oxygenase- 1 in a phosphatidylinositol 3-kinase-dependent manner. J Biol Chem 278:13898-13904.

Sherer TB, Trimmer PA, Borland K, Parks JK, Bennett Jr JP, Tuttle JB (2001) Chronic reduction in complex I function alters calcium signaling in $\mathrm{SH}-$ SY5Y neuroblastoma cells. Brain Res 891:94-105.

Sherer TB, Kim JH, Betarbet R, Greenamyre JT (2003a) Subcutaneous rotenone exposure causes highly selective dopaminergic degeneration and alpha-synuclein aggregation. Exp Neurol 179:9-16.

Sherer TB, Betarbet R, Testa CM, Seo BB, Richardson JR, Kim JH, Miller GW, Yagi T, Matsuno-Yagi A, Greenamyre JT (2003b) Mechanism of toxicity in rotenone models of Parkinson's disease. J Neurosci 23:10756-10764.

Shults CW, Ray J, Tsuboi K, Gage FH (2000) Fibroblast growth factor-2producing fibroblasts protect the nigrostriatal dopaminergic system from 6-hydroxydopamine. Brain Res 883:192-204.

Siegel GJ, Chauhan NB (2000) Neurotrophic factors in Alzheimer's and Parkinson's disease brain. Brain Res Brain Res Rev 33:199-227.

Takayama H, Ray J, Raymon HK, Baird A, Hogg J, Fisher LJ, Gage FH (1995) Basic fibroblast growth factor increases dopaminergic graft survival and function in a rat model of Parkinson's disease. Nat Med 1:53-58.

Tooyama I, Kawamata T, Walker D, Yamada T, Hanai K, Kimura H, Iwane M, Igarashi K, McGeer EG, McGeer PL (1993) Loss of basic fibroblast growth factor in substantia nigra neurons in Parkinson's disease. Neurology 43:372-376.

Tooyama I, McGeer EG, Kawamata T, Kimura H, McGeer PL (1994) Retention of basic fibroblast growth factor immunoreactivity in dopaminergic neurons of the substantia nigra during normal aging in humans contrasts with loss in Parkinson's disease. Brain Res 656:165-168.

Ugarte SD, Lin E, Klann E, Zigmond MJ, Perez RG (2003) Effects of GDNF on 6-OHDA-induced death in a dopaminergic cell line: modulation by inhibitors of PI3 kinase and MEK. J Neurosci Res 73:105-112.

Vlahos CJ, Matter WF, Hui KY, Brown RF (1994) A specific inhibitor of phosphatidylinositol 3-kinase, 2-(4-morpholinyl)-8-phenyl-4 $H$-1benzopyran-4-one (LY294002). J Biol Chem 269:5241-5248.

Walker DG, Terai K, Matsuo A, Beach TG, McGeer EG, McGeer PL (1998) Immunohistochemical analyses of fibroblast growth factor receptor-1 in the human substantia nigra. Comparison between normal and Parkinson's disease cases. Brain Res 794:181-187.

Wanaka A, Johnson Jr EM, Milbrandt J (1990) Localization of FGF receptor mRNA in the adult rat central nervous system by in situ hybridization. Neuron 5:267-281.

Wanaka A, Milbrandt J, Johnson Jr EM (1991) Expression of FGF receptor gene in rat development. Development 111:455-468.

Wang G, Qi C, Fan GH, Zhou HY, Chen SD (2005a) PACAP protects neuronal differentiated PC12 cells against the neurotoxicity induced by a mitochondrial complex I inhibitor, rotenone. FEBS Lett 579:4005-4011.

Wang HG, Rapp UR, Reed JC (1996) Bcl-2 targets the protein kinase Raf-1 to mitochondria. Cell 87:629-638.

Wang SW, Denny TA, Steinbrecher UP, Duronio V (2005b) Phosphorylation of Bad is not essential for PKB-mediated survival signaling in hemopoietic cells. Apoptosis 10:341-348.

Wang X, Qin ZH, Leng Y, Wang Y, Jin X, Chase TN, Bennett MC (2002) Prostaglandin A1 inhibits rotenone-induced apoptosis in SH-SY5Y cells. J Neurochem 83:1094-1102.

Watabe M, Nakaki T (2004) Rotenone induces apoptosis via activation of bad in human dopaminergic SH-SY5Y cells. J Pharmacol Exp Ther 311:948-953

Xia Z, Dickens M, Raingeaud J, Davis RJ, Greenberg ME (1995) Opposing effects of ERK and JNK-p38 MAP kinases on apoptosis. Science 270:1326-1331.

Yao R, Cooper GM (1995) Requirement for phosphatidylinositol-3 kinase in the prevention of apoptosis by nerve growth factor. Science 267:2003-2006.

Zha JP, Harada H, Yang E, Jockel J, Korsmeyer SJ (1996) Serine phosphorylation of death agonist $\mathrm{BAD}$ in response to survival factor results in binding to 14-3-3 not BGL-X(L). Cell 87:619-628. 